\title{
SUSTAINABILITY STRATEGIES IN NATURE
}

\author{
Y. H. COHEN ${ }^{1}$, Y. REICH ${ }^{2}$ \& S. GREENBERG ${ }^{3}$ \\ ${ }^{1}$ Porter School of Environmental Studies, Tel Aviv University, Israel. \\ ${ }^{2}$ School of Mechanical Engineering, Tel Aviv University, Israel. \\ ${ }^{3}$ Holon Institute of Technology, Faculty of Sciences, Israel.
}

\begin{abstract}
Nature is a source of knowledge and inspiration for sustainable innovative solutions. Through biomimetic design, nature solutions are studied, abstracted and transferred to technology and other domains of applications. Sustainability and ideality are basic notions in design. While ideal systems had always been aspired for, having sustainable systems is a relatively new demand. In this paper we explore the similarity and differences between these two basic notions and suggest that there is a strong relation between ideality and sustainability. Based on this relation we analysed biological systems by a particular ideality framework and identified repeated ideality strategies and design principles in nature. Selected examples of ideality analyses are presented as well as the list of ideality strategies that repeat in nature and represent nature sustainability strategies. These ideality strategies enrich current knowledge of sustainability strategies in nature (the life principles) by new operative and descriptive strategies. Ideality strategies are derived from a technical view that might be more inherent and applicable for engineers, observing biological systems as if they were technical systems. Using the ideality framework and strategies as a sustainability tool to address sustainable biomimetic design processes is further discussed.

Keywords: Biomimicry, ideality, life principles, sustainable biomimetic design, sustainability strategies in nature, TRIZ.
\end{abstract}

\section{INTRODUCTION}

One of the major challenges of humanity today is to provide sustainable technologies. Resources and ecosystem services are declining while their demand increases [1]. We still depend on oil, carbon emissions are getting higher and high percentage of the raw material is wasted during manufacturing processes [2]. It is clear that a real change is required and should be inherent in the way we think, design, manufacture, consume and end the use of our products.

Various sustainability tools are developed for this purpose. Research findings support the argument that environmental parameters should be integrated during the design stages that determine most of the environmental impact [3]. Among these design stages, conceptual design is considered to have the most influence on the final product [4], but it lacks detailed information about material and energy consumption that is usually required for sustainability design and assessment [5]. Applying sustainability during design concept stage should be more based on sustainability strategies and design principles that could be derived from nature.

Seeking nature guidance for sustainable models and measures is reasonable and has expanded in the last years through biomimetic design processes. Biological systems operate within restricted living constraints without creating waste or irreversible damage to the ecosystem. On the contrary, they enrich and sustain ecosystems. Nature forms and structures provide a wide range of properties with the minimal use of material or energy. Nature manufacturing processes are conducted within life and therefore avoid high temperature, strong pressures or toxic materials [6]. Nature systems demonstrate efficient flows of energy and material.

However, using nature for practical sustainable solutions is challenging because locating sustainability strategies in nature and transforming them into applicable design principles is not easy. These strategies are sustainability patterns that repeat among various organisms at multiple scales and 
represent nature design solutions to survive and sustain under life constraints. They are considered in the literature as the life principles. Sustainable design patterns are fundamental units of the biomimetic analogical transfer [7] and therefore their identification is crucial for the success of the biomimetic design process. Designers who implement these strategies during the design process or use them as metrics may foster sustainability [8].

Various attempts have been done to define the life principles [6, 9-11]. Reap [12] identified sustainable design principles in ecosystems and offered to integrate them during the design process. The core knowledge is summarized in the life principles framework of Biomimicry 3.8 [13].

The Biomimicry 3.8 life principles include six major strategies and twenty design principles that nature follows in order to survive, subject to earth operating conditions, limits and boundaries. Some of these life principles are general and their application in engineering is neither clear nor straightforward. There is not much evidence for their completeness and it is unclear how they were revealed and how to search for new ones. A designer may use the accumulated knowledge about life principles but can't use them as a framework to find more sustainability strategies in nature. In addition, there is not much evidence for their practical use, at least at the academic literature. There is a need for a framework that could lead the search for more sustainability strategies in nature and formulate them in an applicable way for technological applications.

One suitable way to bridge biology and technology is TRIZ, the 'theory of inventive problemsolving' [14]. TRIZ has been used for analyzing biological systems through technical lenses, bridging the gap between biology and technology [15,16]. The BioTRIZ study [17] located solutions for design conflicts in nature, but the TRIZ potential to promote biomimetic design is not exhausted, especially in terms of sustainability. In this paper we offer the TRIZ ideality framework for the purpose of searching and formulating sustainability strategies and design principles in nature.

\section{RELATIONS OF IDEALITY AND SUSTAINABILITY}

Ideality and sustainability are basic notions in the TRIZ and in the design literature respectively. While ideal systems had always been aspired for, Hving sustainable systems is a relatively new demand. Ideality is derived from the word 'idea' implying an imaginary state that exists only as an idea but should be endeavoured. According to TRIZ, ideality is defined as the qualitative ratio of system useful functions to its harmful functions (Fig. 1). Useful functions are the benefits that the system provides and harmful functions are the undesired costs or the system operation, such as recourses, noise, waste, pollution, etc. According to the TRIZ law of Ideality, and as presented in Fig. 1, any technical system tends to become more ideal throughout its lifetime, providing more benefits at less costs. The ideal final result is a hypothetical state of having all benefits at zero cost [14].

Sustainability is based on the combination of the words 'sustain' and 'ability'. It is defined as the ability to be used without being completely used up or destroyed, or the ability to last or continue for a long time (Merriam Webster Dictionary). Assuming that resources are limited, a relevant strategy to sustain is to 'achieve more with less' which means achieving more benefits with less resources. The relation to Ideality is clear. Sustainability may be achieved by ideal systems that provide more benefits at lesser costs.

$$
\text { Ideality }=\frac{\text { All Useful funtions }}{\text { All Harmful functions }}=\frac{\text { Benefits }}{\text { Costs }} \rightarrow \infty
$$

Figure 1: The TRIZ Ideality Framework. 
The idea of minimizing negative impacts and maximizing positive impacts has already been related to sustainability. Charter \& Tischner [18] defined sustainable solutions as ones that minimize adverse sustainability impacts (economic, environmental, social and ethical) and maximize sustainable value, throughout the life-cycle of existing products or solutions. Hill [19] expressed a similar idea when he defined the effectiveness of biological structures as a cost-benefit relation between maximization of the 'survival functions' (including sub-functions such as reproduction, feeding, defence and movement) and minimization of costs (energy use and biomass).

The relation between sustainability and ideality was a base for the development of practical ecoguidelines for product innovation and sustainability [20,21]. Here we offer to use this relation for biomimetic design. The ideality definition of 'achieving more with less' is clearly applicable for biological systems. Due to a competition on resources and the fact that some of the used resources are not renewed at the required rate, biological systems must demonstrate ideal architecture, structures and processes in order to sustain.

While searching for general sustainability strategies or life principles is difficult or not always clear, searching for ideality strategies is well directed by a simple principle of increasing system benefits and reducing system costs.

\section{THE METHOD}

We analyzed several biological systems by the TRIZ ideality framework (Fig. 1). Biological systems were taken from our research database, a database of biomimetic designs sorted by structures. This database was built for a previous study on nature structure-function patterns [22] and includes biological systems extracted from different biomimetic sources [10, 23, 24]. We analyzed several biological systems, few of each structural pattern that was identified in our previous study [22], by the ideality framework. We chose to focus on these systems as they represent a sample of generic structures that repeat in nature in different systems and scales, demonstrating nature efficient solutions to the design space limits. As these structures are generic, they might represent generic ideality strategies as well.

For each biological system we used a two stage analysis. First, we searched for general strategies to increase benefits and reduce costs, without a reference. Then we used technological ideality strategies extracted from TRIZ literature [25], [26] as a reference (Table 1), and identified similar strategies in nature. Each strategy was elaborated to include various design principles that achieve it.

Table 1: Technological ideality strategies.

Ideality strategy

Increase benefits Adding functions to the existing working parts

Improve the performance of some functions

Exclude auxiliary functions that support the main function but may be removed without affecting the performance of the main function Combine subsystems of several functions into a single system Transferring some functions to a super-system Utilizing internal and external resources that already exist and are available

Reduce costs Use of physical, chemical, geometrical and other effects as resources Improving the conductivity of energy through the system (easier access) Synchronization of system parameters to prevent waste 


\section{RESULTS}

Nature ideality strategies and design principles are presented in Table 2 including example for each design principle. The iteration of each design principle in the sample (Table 3) is presented bolded in brackets. Examples for ideality analyses for selected biological systems representing various structural patterns are provided in Table 3 .

\section{DISCUSSION}

\subsection{The characteristics of ideality strategies and design principles}

We analysed numerous biological systems representing various structural patterns in nature by the TRIZ ideality framework. The result is a list of repeated sustainability strategies and design principles in nature (Table 2) and a framework to search for others in the future (Fig. 1).

It is interesting to realize that increasing ideality by reducing costs is more prevalent in nature ( 8 design principles) compared to increasing ideality by increasing benefits ( 2 design principles). The cases presented in Table 3 demonstrate more strategies to reduce costs but in all cases there is at least one strategy to increase benefits. Some ideality design principles are more frequent, such as 'Multifunctional design' and 'Adjustment of structure to function' that appear in all cases and considered to be basic design principles in nature.

It is also interesting to realize that most nature ideality strategies (Table 2) have matching strategies in technology (Table 1). Using ideality strategy in technology as a reference (Table 1) was valuable and illuminated similar strategies in nature.

\subsection{Ideality versus life principles}

Comparing ideality strategies with life principles reveals the similarities and differences between them. The ideality strategies partially overlap the life principles and in some cases complete and enrich them. For example, 'Multifunctional design' and 'Adjustment of structure to function' appear in both lists with similar wording. In other cases similar principles appear in both lists but the life principles are more general while the ideality strategies are more operative and descriptive. For example, the life principle of 'Use readily available materials and energy' may not be operative enough as it does not provide the answer where these available energy and material resources may be found. In contrast, the related ideality principle of using physical, chemical, geometrical and other effects and gradients as energy resources provide the answer where to find available resources. Another example is the life principle 'Use feedback loops' that may not be operative enough as it does not provide the answer for how to use the feedback loops. In contrast, the related ideality principle of 'Synchronizing system parameters' suggests using feedback loops by synchronizing system parameters with environmental parameters.

The ideality strategies enrich and complete the life principles with extended design principles for the same subject. For example, while reacting to disturbances appearing in both frameworks, the life principle suggests managing disturbances by resilience through variation, redundancy, and decentralization. The ideality principle suggests reducing external disturbances such as friction, loads, turbulence and more by adjusting structures and by decreasing surface area when it has harmful effect.

Life principles are based on a holistic approach viewing the organism as part of its ecosystem. The ideality framework is based on a technical and functional view. For example, the life principle ' $\mathrm{Cul}-$ tivate cooperative relationship' is based on holistic approach of win-win relationship. The related 
ideality principle of 'Transferring some functions to the super-systems' mainly view the functional benefits to the system though the super-system element may be also an organism that gain a function through a symbiotic relationship.

Through the lens of ideality, we revealed a new sustainable design principle in nature: Intensify the interaction with the environment to achieve extended or stronger effect by repetition of elements and / or by increased surface area.

Life principles that do not appear in the ideality strategies mainly refer to the growth and manufacturing processes such as recycling, self-organization and water based chemistry. So far, our analyses focused on current functioning of structures and did not observe how did they form or end their life. However, the framework of ideality may identify these aspects if we enlarge our scope of analysis. For example, recycling all materials is relevant to the ideality strategy of 'Prevent waste for better usage of resources'. Generally, life principles include more strategies and design principles, but the ideality strategies may be extended in future research as the searching framework is simple and clear.

In summary, the ideality framework is a simple framework of reference and a way of thinking that may be used for the process of identifying sustainable aspects in nature. The ideality framework partially overlaps the life principles and in some cases completes and enriches it.

\subsection{Ideality as a tool for sustainable design}

The ideality strategies (Table 2) are sustainability patterns extracted from nature. They are suggested as sustainability tools adjusted to early design stages of conceptual design, as they do not require detailed information about material and energy flows.

A designer may use the ideality strategies as a checklist tool and implement them at the conceptual design as design principles that foster sustainability. Thus, ideality strategies are adjusted for general design processes, not only for biomimetic design processes.

In relation to biomimetic design, a designer may analyze the ideality aspects of a specific biological role model by the ideality framework (qualitative ratio of benefits to costs) and by the assistance of Table 2 as a reference. Then, the designer could repeat this ideality analysis process for the related biomimetic design concept. The comparison between these two analyses reassures that the sustainability strategies of the biological model are kept and transferred to technology. In a metaphoric way we use this comparison to reassure we don't lose some degrees of ideality during the transfer from biology to technology. As we move to discuss biomimetic design we must acknowledge that biomimetic design has a potential to promote sustainability but sustainability is not guaranteed. A designer may imitate an innovative design concept from nature but perform it using harmful materials and pollutant manufacturing processes. In order to foster sustainability there is a need for sustainability tool such as the ideality framework.

Besides the current list of ideality strategies (Table 2), the ideality framework itself may guide the search for more ideality strategies in nature, enriching Table 2 with new insights. Whereas the life principles are a closed core of knowledge, as a designer may use them but not direct his own search for new life principles.

\subsection{Innovative aspects and future research}

The innovative aspects of this study are mainly related to viewing biological system through a technical lens of the ideality framework, originally developed for technical systems. We used technological knowledge, (Fig. 1 and Table 1) to identify biological knowledge that in turn will be infused back to technology through biomimetic design processes. The ideality strategies enrich 
Table 2: Nature ideality strategies and design principles.

\begin{tabular}{|c|c|c|c|}
\hline & General strategy & Design principle & General example \\
\hline \multirow[t]{2}{*}{$\begin{array}{l}\text { Increased } \\
\text { benefits }\end{array}$} & More Functions & $\begin{array}{l}\text { 1) Multifunctional Design ( } 7) \text { - } \\
\text { Increase the number of functions } \\
\text { that are related to one structure } \\
\text { by unification of system parts. }\end{array}$ & $\begin{array}{l}\text { Tree roots provide the } \\
\text { function of channelling } \\
\text { (nutrients and water) and } \\
\text { the function of stability. }\end{array}$ \\
\hline & $\begin{array}{l}\text { Stronger effect of } \\
\text { one function }\end{array}$ & $\begin{array}{l}\text { 2) Intensify the interaction with } \\
\text { the environment to achieve ex- } \\
\text { tended or stronger effect of } \\
\text { one function by (4): } \\
\checkmark \text { Repetition of elements } \\
\checkmark \text { Increased surface area }\end{array}$ & $\begin{array}{l}\text { Repetition of pulmonary } \\
\text { alveolus extends the gas } \\
\text { exchange surface area, } \\
\text { resulting in extended gas } \\
\text { exchange. }\end{array}$ \\
\hline \multirow[t]{8}{*}{$\begin{array}{l}\text { Reduced } \\
\text { costs }\end{array}$} & \multirow{2}{*}{$\begin{array}{l}\text { Defensive Strategy- } \\
\text { Preventing distur- } \\
\text { bances and harmful } \\
\text { effects. } \\
\text { Saving the costs of } \\
\text { disturbances }\end{array}$} & $\begin{array}{l}\text { 3) Reduction of disturbances } \\
\text { such as friction, loads, turbulence } \\
\text { and more by structures ( } 6 \text { ) }\end{array}$ & $\begin{array}{l}\text { Honeycomb structure re- } \\
\text { duces external load effects. }\end{array}$ \\
\hline & & $\begin{array}{l}\text { 4) Decrease of surface area when } \\
\text { it has harmful effects (1) }\end{array}$ & $\begin{array}{l}\text { Minimizing surface area } \\
\text { of desert leaves to reduce } \\
\text { water loss by evaporation. }\end{array}$ \\
\hline & \multirow[t]{3}{*}{$\begin{array}{l}\text { Opportunist } \\
\text { Strategy - Usage of } \\
\text { available resources } \\
\text { to save costs }\end{array}$} & $\begin{array}{l}\text { 5) Usage of physical, chemical, } \\
\text { geometrical and other effects and } \\
\text { gradients as energy resources- } \\
\text { saving energy costs (4) }\end{array}$ & $\begin{array}{l}\checkmark \text { Using wind energy to } \\
\text { disperse seeds } \\
\checkmark \text { Using temperature gra- } \\
\text { dient to transfer heat }\end{array}$ \\
\hline & & $\begin{array}{l}\text { 6) Adjustment of structure to } \\
\text { function: structure provides the } \\
\text { function-saving material costs } \\
\text { (7) }\end{array}$ & $\begin{array}{l}\text { The tubular structure of } \\
\text { roots enables their penetra- } \\
\text { tion into soil }\end{array}$ \\
\hline & & $\begin{array}{l}\text { 7) Transferring some functions to } \\
\text { the super-system (saving material } \\
\text { costs). Using super-system } \\
\text { material resources. ( } 3 \text { ) }\end{array}$ & $\begin{array}{l}\text { Puffer fish uses water from } \\
\text { the super-system to blow } \\
\text { their body }\end{array}$ \\
\hline & \multirow[t]{3}{*}{$\begin{array}{l}\text { Prevent waste for } \\
\text { better usage of } \\
\text { resources }\end{array}$} & $\begin{array}{l}\text { 8) Synchronizing system param- } \\
\text { eters to prevent waste ( } 2 \text { ) }\end{array}$ & $\begin{array}{l}\text { Synchronizing seeds ger- } \\
\text { mination with environmen- } \\
\text { tal humid levels }\end{array}$ \\
\hline & & $\begin{array}{l}\text { 9) Improving the conductivity } \\
\text { of energy through the system to } \\
\text { provide easier access and prevent } \\
\text { waste of energy (4) }\end{array}$ & $\begin{array}{l}\text { The network structure } \\
\text { of the tree root system } \\
\text { provides easier conduction } \\
\text { and prevent loss of energy }\end{array}$ \\
\hline & & 10) Give up redundant parts (2) & $\begin{array}{l}\text { Give up redundant filling } \\
\text { material in bones provide } \\
\text { lightweight bone and save } \\
\text { material and energy }\end{array}$ \\
\hline
\end{tabular}


Table 3: Selected examples of ideality analyses per various structural patterns.

\begin{tabular}{|c|c|c|c|}
\hline & Patterns & Example & $\begin{array}{l}\text { Ideality analysis (Each design principle has a number as } \\
\text { presented in Table 2) }\end{array}$ \\
\hline 1 & $\begin{array}{l}\text { Repeated } \\
\text { Protrusions }\end{array}$ & $\begin{array}{l}\text { Lotus } \\
\text { leaf [27] }\end{array}$ & $\begin{array}{l}\text { Increased benefits: } \\
\text { 1. Multifunctional design: The epidermal protrusions provide } \\
\text { both dirt removal and protection against bacteria [28] } \\
\text { 2. Intensified interaction: Stronger effect of dirt removal is } \\
\text { achieved by the repetition of protrusions. } \\
\text { Reduced Costs: } \\
\text { 3. Reduction of external disturbance: removal of dirt that can } \\
\text { harm the photosynthesis process. Removal of harmful bacteria. } \\
\text { 5. Usage of physical effects: using adhesion and gravitation } \\
\text { gradients for the dirt removal function. } \\
\text { 6. Adjustment of structure to function: Epidermal protrusions } \\
\text { create superhydrophobic structure, adjusted to dirt removal. } \\
\text { 7. Transferring some functions to the super-system: The water } \\
\text { droplets actually remove the dirt particles. } \\
\text { 8. Synchronizing system parameters: dirt removal is synchro- } \\
\text { nized with the appearance of water to prevent waste of light } \\
\text { energy. }\end{array}$ \\
\hline 2 & $\begin{array}{l}\text { Repeated } \\
\text { channels/ } \\
\text { tubes }\end{array}$ & $\begin{array}{l}\text { Termite } \\
\text { mound [29] }\end{array}$ & $\begin{array}{l}\text { Increased Benefits: } \\
\text { 1. Multifunctional design: tunnels provide both stability and a } \\
\text { path for the air flow. } \\
\text { 2. Intensified interaction: repetition of tunnels increases the sur- } \\
\text { face area, achieving stronger effect of gas exchange regulation. } \\
\text { Reduced costs: } \\
\text { 3. Reduction of external disturbance: tubular structure of the } \\
\text { tunnels system protect against external harmful loads. } \\
\text { 5. Usage of physical effects: Supporting diverse physical } \\
\text { phenomena related to heat transfer. Saving energy cost of air } \\
\text { movement. } \\
\text { 6. Adjustment of structure to function: tunnels are adjusted for } \\
\text { channeling air. Tubular shape is adjusted to absorb loads. } \\
\text { 7. Transferring some functions to the super-system: Fungi that } \\
\text { live inside the mound provide food and get a shelter (symbio- } \\
\text { sis). } \\
\text { 9. Improving the conductivity by the network of tunnels that } \\
\text { provide easier access for the air flow. }\end{array}$ \\
\hline 3 & $\begin{array}{l}\text { Asymmetric } \\
\text { structures }\end{array}$ & $\begin{array}{l}\text { Pine cone } \\
\text { scales } \\
{[30]}\end{array}$ & $\begin{array}{l}\text { Increased benefits: } \\
\text { 1. Multifunctional design: pine cone scales contain, protect and } \\
\text { release the seeds. } \\
\text { 2. Intensify the interaction: repetition of scales enable contain- } \\
\text { ing and releasing more seeds. }\end{array}$ \\
\hline
\end{tabular}

(Continued) 


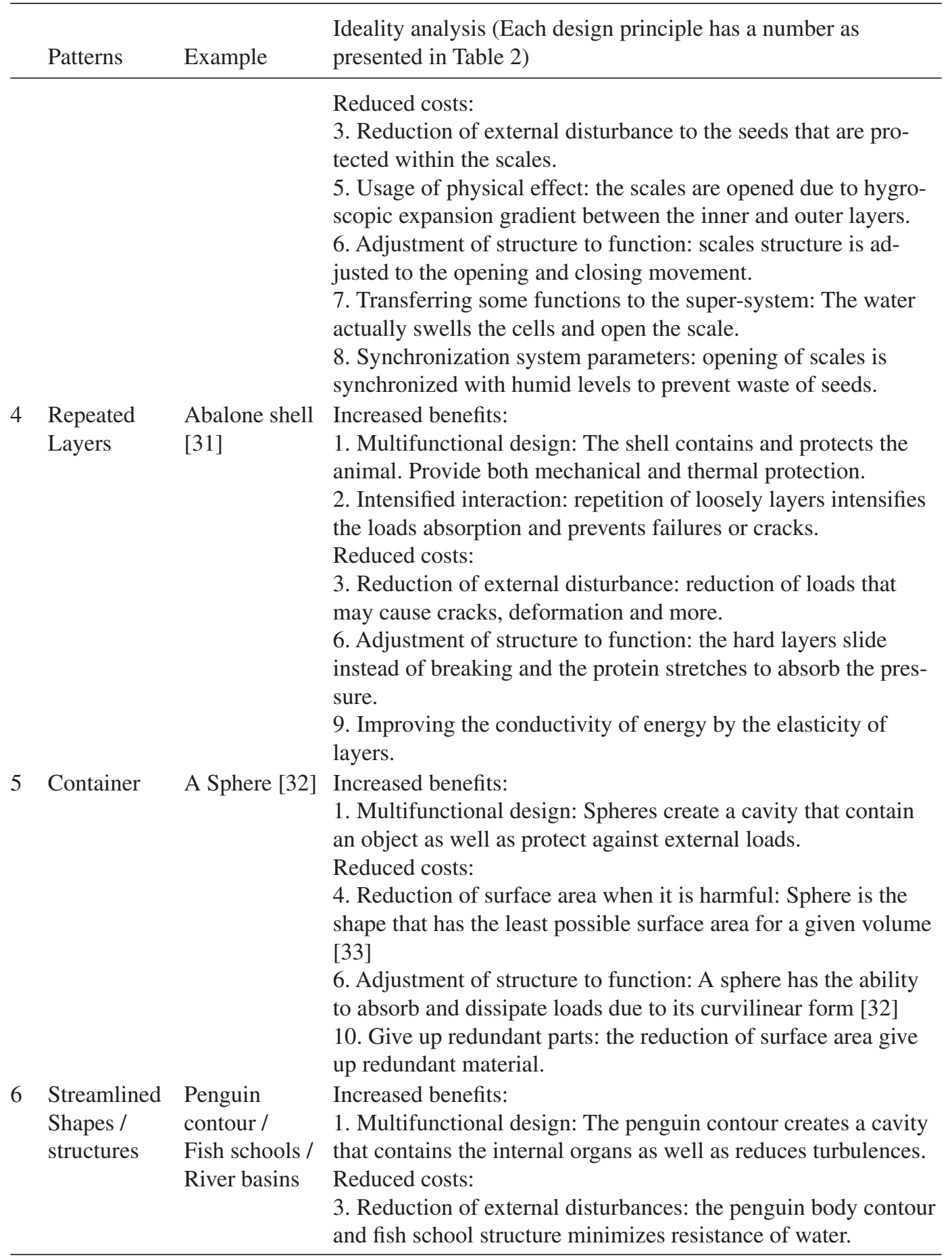

(Continued) 


\begin{tabular}{|c|c|c|c|}
\hline & Patterns & Example & $\begin{array}{l}\text { Ideality analysis (Each design principle has a number as } \\
\text { presented in Table 2) }\end{array}$ \\
\hline 7 & $\begin{array}{l}\text { Cylinder/ } \\
\text { Tube }\end{array}$ & Tree roots & $\begin{array}{l}\text { 5. Usage of physical effects: fish schools create positive con- } \\
\text { structive hydrodynamic between wakes and use it for propul- } \\
\text { sion [34] } \\
\text { 6. Adjustment of structure to function: streamlined shapes con- } \\
\text { sist of curvilinear forms that absorb and dissipate loads [32]. } \\
\text { 9. Improving the conductivity of energy: easier flow in river } \\
\text { basins (network structure), corresponding to constructal theory } \\
\text { [35]. } \\
\text { Increased benefits: } \\
\text { 1. Multifunctional design: tree roots provide stability, easier } \\
\text { penetration and channeling of water and nutrients. } \\
\text { Reduced costs: } \\
\text { 3. Reduction of disturbance: reduction of loads by providing } \\
\text { stability against bending and buckling [36]. } \\
\text { 6. Adjustment of structure to function: the tubular structure of } \\
\text { the tree roots is adjusted to the function of penetrating into the } \\
\text { soil. } \\
\text { 9. Improving the conductivity of energy: easier flow in the roots } \\
\text { network structures, corresponding to constructal theory [35]. } \\
\text { 10. Give up redundant parts: hollow tube (giving up filling) is } \\
\text { more difficult to bend compared to a whole one [37] }\end{array}$ \\
\hline
\end{tabular}

current knowledge of sustainability strategies in nature (life principles) by new operative and descriptive strategies. Ideality strategies are derived from a technical view that might be more inherent and applicable for engineers.

Future research should extend the scope of ideality analysis, analyzing other biological structures, processes and systems, revealing more ideality strategies and principles. Field experiments could evaluate the ideality framework as a sustainability tool and assess its advantage in terms of validity and reliability. Finally, the integration of the ideality tool within a biomimetic design process should be further discussed and demonstrated by case studies.

As we stated at the beginning, there is a need for a real change in the way we think, design, manufacture, consume and end the use of our products. Nature offers a paradigm shift towards sustainability that can be realized by the ideality framework and nature ideality strategies.

\section{REFERENCES}

[1] http://www.naturalstep.org/ [cited 24 January 2013].

[2] Hawken, P., Lovins, A.B. \& Lovins, L.H., Natural Capitalism: The Next Industrial Revolution, Earthscan, 2010. doi: http://dx.doi.org/10.1002/1099-1719(200008)8:3\%3C165::aidsd142\%3E3.0.co;2-s

[3] Fitzgerald, D.P., et al., Beyond tools: a design for environment process. International Journal of Performability Engineering, 1(2), p. 105, 2005 
[4] Ullman, D.G., The Mechanical Design Process, 4th edn., McGraw-Hill Higher Education, 2010.

[5] Tukker, A., Life cycle assessment as a tool in environmental impact assessment. Environmental Impact Assessment Review, 20(4), pp. 435-456, 2000. doi: http://dx.doi.org/10.1016/s01959255(99)00045-1

[6] Benyus, J., M. Biomimicry: Innovation Inspired by Nature, Quill: New York, 1997. doi: http:// dx.doi.org/10.2307/4450504

[7] Goel, A.K., et al., Design Patterns and Cross-Domain Analogies in Biologically Inspired Sustainable Design. AAAI Spring Symposium Series, 2011.

[8] Faludi, J., Biomimicry place in green design. Zygote Quarterly. pp. 120-129, 2012.

[9] Hoeller, N., Salustri, F., DeLuca, D., Pedersen, Z., Love, M., McKeag, T., Stephers, F., Reap, J. \& Sopchac, L., Patterns from Nature, in Proceedings of the SEM Annual Conference and Exposition on Experimental and Applied Mechanics. Massachusetts, USA, 2007.

[10] www.biomimicryinstitute.org [cited 24 January 2013].

[11] Zari, M.P., Biomimetic Approaches to Architectural Design for Increased Sustainability. School of architecture, Victoria University: New Zealand, 2007.

[12] Reap, J.J., Holistic biomimicry: a biologically inspired approach to environmentally benign engineering, Thesis, 2009.

[13] http://biomimicry.net/about/biomimicry/biomimicry-designlens/lifes-principles/ [cited 24 January 2013]. doi: http://dx.doi.org/10.1016/b978-0-12-415995-2.00019-2

[14] Altshuller, G., The Innovation Algorithm, TRIZ, Systematic Innovation and Technical Creativity. Worcester, MA: Technical Innovation Center, Inc., 1999.

[15] Helfman Cohen, Y., Reich,Y. \& Greenberg S., What can we learn from biological systems when applying the law of system completeness? ETRIA European TRIZ Association, Dublin, 2011.

[16] Helfman Cohen, Y., Reich, Y. \& Greenberg, S., Substance Field Analysis and Biological Functions, ETRIA European TRIZ Association, Lisbon, 2012.

[17] Vincent, J.F., et al., Biomimetics: its practice and theory. J R Soc Interface, 3(9), pp. 471-82, 2006.

[18] Charter, M. \& Tischner, U., Sustainable Solutions: Developing Products and Services for the Future, Greenleaf publishing, 2001. doi: http://dx.doi.org/10.9774/gleaf.978-1-907643-21-7 8

[19] Hill, B., Goal setting through contradiction analysis in the Bionics oriented construction process. Creativity and Innovation Management, 14(1), pp. 59-65, 2005. doi: http://dx.doi. org/10.1111/j.1476-8691.2005.00325.x

[20] Chen, J.L. \& Yang, Y.-C. Eco-Innovation by Integrating Biomimetic with TRIZ Ideality and Evolution Rules, in Glocalized Solutions for Sustainability in Manufacturing, Springer, pp. 101-106, 2011. doi: http://dx.doi.org/10.1007/978-3-642-19692-8 18

[21] Russo, D., Regazzoni, D. \& Montecchi, T., Eco-design with TRIZ laws of evolution. Procedia Engineering, 9, pp. 311-322, 2011. doi: http://dx.doi.org/10.1016/j.proeng.2011.03.121

[22] Helfman Cohen, Y., Reich, Y. \& Greenberg, S., Biomimetics: Structure-function patterns approach. Journal of Mechanical Design, 2014. (Submitted for publication). doi: http://dx.doi. org/10.1115/1.4028169

[23] www.asknature.org [cited 24 January 2013].

[24] www.biomimicrynews.org [cited 24 January 2013].

[25] Terninko, J.Z. \& Zlotin, A.B., Systematic Innovation: An Introduction to Triz, St. Lucie Press, 1998.

[26] TRIZ Solutions LLC, Law of technical system evolution Presentation. [cited 24 January 2013]. 
[27] Solga, A., et al., The dream of staying clean: Lotus and biomimetic surfaces. Bioinspiration \& Biomimetics, 2(4), p. 126, 2007. doi: http://dx.doi.org/10.1088/1748-3182/2/4/s02

[28] Oksman-Caldentey, K.-M. \& Barz, W.H., Plant biotechnology and transgenic plants, 92, 2002. doi: http://dx.doi.org/10.1201/9780203910849

[29] Turner, J.S. \& Soar, R.C., Beyond biomimicry: What termites can tell us about realizing the living building. Proc. 1st Int. Conf. Industrialized, Intelligent Construction, 2008.

[30] Dawson, C., Vincent, J.F. \& Rocca, A.-M., How pine cones open. Nature, 390(6661), p. 668, 1997. doi: http://dx.doi.org/10.1038/37745

[31] Smith, B.L., et al., Molecular mechanistic origin of the toughness of natural adhesives, fibres and composites. Nature, 399(6738), pp. 761-763, 1999.

[32] Tsui, E., Evolutionary Architecture-Nature as a Basis for Design, New York: John Wiley \& sons, 1999.

[33] Foy, S., The Grand Design: Form and Colour in Animals. Prentice-Hall, Inc., 1983.

[34] www.caltech.edu [cited 24 January 2013].

[35] Bejan, A., Shape and Structure, From Engineering to Nature, Cambridge University Press, 2000. doi: http://dx.doi.org/10.2298/tsci0601141r

[36] Thompson, D., On Growth and Form: Cambridge University Press, 1966. doi: http://dx.doi. org/10.1002/bimj.19690110510

[37] Vogel, S., Life's Devices - The Physical World of animals and plants. Princeton University Press, 1988. doi: http://dx.doi.org/10.1016/0169-5347(89)90128-6 